\title{
The Influence of Gender and Ethnicity on Young Adults' Participation in Financial Education Programme
}

\author{
Mohamad Fazli Sabri ${ }^{1} \&$ Rusitha Wijekoon ${ }^{2}$ \\ 1,2 Department of Resource Management \& Consumer Studies, Faculty of Human Ecology, Universiti Putra \\ Malaysia, 43400 UPM Serdang, Selangor, Malaysia \\ Correspondence: Mohamad Fazli Sabri, Associate Professor, Department of Resource Management \& Consumer \\ Studies, Faculty of Human Ecology, Universiti Putra Malaysia, 43400 UPM Serdang, Selangor, Malaysia. \\ E-mail: fazli@upm.edu.my
}

Received: April 5, 2019 Accepted: April 30, 2019 Online Published: May 24, 2019

doi:10.5539/jms.v9n1p159 URL: https://doi.org/10.5539/jms.v9n1p159

\begin{abstract}
A major problem encountered by educationalists, community leaders and policy makers is to transfer financial literacy and consumer education successfully to their community. Delivering of financial education for youth of a country is one possible intervention to improve the financial capabilities of a population. Therefore, for an effective training we have to identify their financial needs. Further they need guidance and access for financial knowledge and money management tools. Therefore, the objectives of this study are to identify the training needs of youth by gender and ethnicity about money management and to determine their interest towards it. The sample was comprised of 220 secondary school students from five schools in Greater Klang Valley/Kuala Lumpur with 112 females and 108 males and the data collection was done using self-administered questionnaire. The results shown that about one third of female youths have preferred to participate on financial literacy programs than male youths $(21.5 \%)$. In addition, most of the Malay respondents said that they need more information to take efficient decisions on saving, borrowing and insurance, followed by Indians $(64 \%)$ and Chinese $(61.5 \%)$. The findings of this study would be used to the development of financial empowerment program of youth in Malaysia in order to enhance their financial literacy.
\end{abstract}

Keywords: money management, training needs, financial socialization, financial education

\section{Introduction}

Nowadays people take their own financial decisions at early stages of their life and in order to be successful as adults they also require good financial skills and knowledge, but according to the existing statistics the financial literacy of young people is poor (Sherraden, Johnson, Guo, \& Elliott, 2011). The development of financial literacy and money management skills of all ages of youth is difficult to understand and it is a critical issue. When understanding monetary and money related ideas by kids they get data significantly from their family, their companions, and the media, just as in school.

The money related administration definitions are differing as indicated by how we measure the host's individual attributes, top choices, and abilities related to the capacity to adapt to one's personal finances (Howlett, Kees, \& Kemp, 2008; Remund, 2010). Therefore, financial knowledge could be considered as a key component of money management, but prevailing literature about how money related information meddle with different qualities to shape the monetary administration is still unclear.

The youngsters gain a knowledge of monetary, and money related ideas with their expanding age, together with concepts for example, banks, savings, credit debit cards and loans. According to the findings of Webley (2005) kids procure enormous advancements in financial comprehension with in the times of somewhere in the range of 6 and 12, and when they reach to the age around 12, their comprehension is actually same as grown-up. Further they may likewise grab facts from their companions and the broad communications on monetary themes for instance, TV advertisements (John, 1999; Sherraden et al., 2011). Exceptionally youthful youngsters initially gain knowledge about monetary administration by means of watching and displaying their parents (Otto, 2009; Sabri, MacDonald, Hira, \& Masud, 2010).

Research discoveries has also revealed that savings behavior to be accompanied with a legitimate child rearing 
style. This inclination demonstrates a relationship with ethnic and socioeconomic backgrounds (Ashby, Schoon, \& Webley, 2011; Otto, 2009). In addition to modeling behavior, parental educating about cash, frequently associate with offering pocket money that influences youngsters' budgetary proficiency and money management effectively. The guardians must always communicate with their youthful kids and young people about the points for example, money management, comparative shopping, and how to save money for the expensive purchases (Moschis, 1985).

As indicated by the discoveries of Grinstein-Weiss, Spader, Yeo, Freeze and Taylor (2011), a significant correlation has been found between revealed parental instructing of money management and higher future credit scores. Despite the fact that, remittances are related with better monetary education and money management behavior of children, given and not given of stipends for the kids by guardians are inadequately comprehended (Ashby et al., 2011; Otto, 2009).

Low levels of financial management may result low dimensions of budgetary prosperity and it makes troublesome for youth to accomplish their monetary needs which are fundamental for living (Hilgert, Hogarth, \& Beverly, 2003; Lusardi \& Mitchell, 2007). Further, , money related proficiency prediction of youth is essencially critical factor because the budgetary learning and abilities that are developed early stages of the life could create an establishment for future monetary conduct and prosperity (Beverly \& Burkhalter, 2005; Martin \& Oliva, 2001).

The identification of Malaysian adolescents training needs on money management by gender and ethnicity are the major purpose of this research. Therefore, the major objectives of this article, are to identify the training needs of youth and to determine the interest and training time periods of the youth by gender and ethnicity on money management. It is important to better understanding of Malaysian teenagers' views about personal financial literacy and their abilities to money management strategies.

\section{Literature Review}

Money attitude is a critical parameter while extending the inspiration to get a surplus monetary administration learning (Edwards, Allen, \& Hayhoe, 2007). Furthermore, monetary information and practices have been ralated with recognitions about cash (Norvilitis, Merwin, Osberg, Roehling, Young, \& Kamas, 2006; Roberts \& Jones, 2001). The writing survey beneath has been focussed significantly on how budgetary socialization specialists, conveyance of financial education, and preference in learning topic related to personal finance impact on youth's level of financial literacy and financial management.

\subsection{Financial Socialization}

Financial socialization can be defined as a process which is acquired by the people from the surroundings those abilities, information, and frames of mind which are important to boost their purchaser job in the financial marketplace (Ward, 1974). The socialization is a process that different shopper attributes which are conveyed from special kind of sources that are usually perceived as socialization operators (Churchill \& Moschis, 1979). The consumer socialization theory, that explins the significance of highlighting social sources with the purpose of hold how clients grab numerous information and behavior (McLeod \& O'Keefe, 1972), is understanding how much buyer socialization specialists energize youth during the time spent receiving and creating purchaser proficiencies, learning, and mentalities.

While thinking of some as variables, for example, the family, companions, schools, and media have been influenced essentially on the customer socialization at the same time, their persuasions are fluctuate in various periods of the lifecycle. As indicated by one of the past investigations of Churchill and Moschis (1979) on young people's customer socialization, family correspondence about utilization matters has been diminished with the age yet peer correspondence with a similar issue would be expanded. In other words, the parental impact is debilitate with the time, then the social standards spread significantly. With the age of youngsters, they find out about customer jobs because of the impact of different socialization operators and their communications which they exposed. Further, youths get an opportunity to improve their money related education through the procedure of socialization (Sohn, Joo, Grable, Lee, \& Kim, 2012).

The relatives, particularly guardians, act as a noteworthy essential socialization specialist for youth and it assumes a critical job when forming cash or sparing mentalities (Clarke, Heaton, Israelsen, \& Eggett, 2005; Rettig, 1985), credit attitudes (Norvilitis et al., 2006), and money related material conglomeration (Lyons, Scherpf, \& Roberts, 2006). For example, $77 \%$ of the secondary school adolescents who were taken part in a work shop on financial literacy had demonstrated plainly their total reliance on the guardians to secure budgetary information (Lyons et al., 2006). 
Another factor which influences the youth's financial behavior is the social norm (Kretschmer \& Pike, 2010; Masche, 2010; Moore \& Bowman, 2006). It has influenced the young peoples' consumer behavior in different ways, for example; product choice (Bachmann, Roedder-John, \& Rao, 1993), present solicitations (Caron \& Ward, 1975), materialistic frames of mind (Churchill \& Moschis, 1979), and consumer competency (Lachance \& Legault, 2007).

Formal education is an another imperative specialist of socialization and it assumes a fundamental job in gaining familiarity on personal finance socialization. In 2005, Varcoe, Martin, Devitto and Go evidenced that, the financial knowledge and behavior of secondary school students could be improved when they utilize a professionally designed financial curriculum in schools.

Nowadays media act as another essential financial socialization operator for youth. Several research have shown that the television advertisements has positive correlation on youths' purchasing bihaviours, brand acknowledgment, materialistic attitudes, and monetary practices (Buijzen \& Valkenburg, 2003; Churchill \& Moschis, 1979; Loibl \& Hira, 2005; Schor, 2004). At long last, above talked about evidenses have been demonstrated the criticalness of money related socialization specialists in sharpning of the budgetary information in young people.

\subsection{Delivery of Financial Education}

Financial education is a process which leads to financial literacy. The OECD's definition of financial education is:

"A process by which financial consumers/investors improve their understanding of financial products and concepts and, through information, instruction and/or objective advice, develop the skills and confidence to become more aware of financial risks and opportunities, to make informed choices, to know where to go for help, and to take other effective actions to improve their financial well-being" (OECD, 2014).

There are compelling reasons for ensuring every child receives financial education early in life and it is an essential literacy for their future. If children get good information early on so that they can build essential monetary and financial ideas, and the financial system that they deal with every day when they become to youth is increasingly straightforward. Johnson and Sherraden (2007) stated that to turn in to a well-developed financial citizen "individuals need to develop financial knowledge and skills but also gain access to financial policies, instruments, and services" (p. 119). Furthermore, they have proposed that budgetary training would be increasingly noteworthy when it associate with psychological learning abilities with genuine monetary encounters, for example, keeping up a ledger. Other literature has revealed that the individuals who have effectively taken an interest in the administration of a remittance, ledger, or other monetary item as an adolescent, spare more as grown-ups (Kotlikoff \& Bernheim, 2001).

Recently, it has been evidenced that the alarming enthusiasm in the popularization and transferring of the information about account for kids, youth and grown-ups in order to upgrade the budgetary education of the families. Different methodologies could be utilized to create and actualize distinctive adaptations of monetary training mediations which are centered around either teaching of youth in the network or youngsters in schools. Further non accessibility of productive financial education through the educational system until now, there are numerous youngsters who have left or are leaving school without the necessary money management skills and information to make informed and wise decisions about money.

Financial education programs that are offered in communities could be generally classified into four types: (a) general budgetary administration (fundamental planning, bank use, and credit the executives) training programs, (b) work environment based retirement training, (c) home proprietorship training, and (d) instruction attached to access to explicit financial items (Collins \& Holden, 2014). Further, consumer educators and community organizations implement various approaches to organize monetary education conveying projects such as informative workshops, leaflets, media use, for example, radio, TV, papers, and post data on the web (Toussaint-Comeau \& Rhine, 2000).

\subsection{Preference in Learning Topic Related to Personal Finance}

Extensive di erences have been recorded on the personal financial skills of adolescents among different nations. For example, young people in the regions of Shanghai-China and the Flemish Community of Belgium demonstrate the most noteworthy normal financial education scores though Colombia, Italy and the Slovak Republic are situated at the base of the scale (OECD, 2014).

The young adults often begin their college careers without ever having been solely responsible for their own personal finances (Cunningham, 2000). Youth financial education programs related to personal finance, 
therefore, are likely to be most successful when delivering the related knowledge to youth. If we know deeply about the public's inclinations in the process of learning topic related to personal finance, financial counseling and planning professionals; instructors, money related establishments and policy makers can efficiently plan and execute monetary training programs in order to fulfill their financial knowledge delivering mission (Rhinei \& Toussaint-Comeau, 2002).

How well young people comprehend the essentials of individual money has positively influenced on the capacity to settle on sound budgetary choices. Opportunities to have a chance for the participation on financial literacy programs is to be an important milestone for these youngsters in their life. Personal finance programs, in this manner, might be the most best method to train those youths on financial literacy. It is further important to guarantee the protection of the consumer from biased, discriminatory or predatory lending practices and these projects can likewise teach them about the the various shopper insurance laws and guidelines (Rhinei \& Toussaint-Comeau, 2002). Propelling buyers towards the better asset building and wealth creation would not just assist them with reaching their financial goals but also contribute to community development (Greenspan, 2002a).

\section{Research Methodology}

\subsection{Sample}

The sample involved a sum of 220 secondary school students from five schools in Greater Klang Valley/ Kuala Lumpur. The selection was done by the school teachers dependent on the criteria from low to middle income with 112 of them were females and 108 of them were males. They were all Form Four secondary school students. Information were acquired through a questionnaire. It was administered and supervised by a trained enumerator in a classroom setting at the particular schools. Data were analyzed utilizing Statistical Package for Social Sciences (SPSS).

\subsection{Measurement and Instrumentation}

\subsubsection{Variables}

\subsubsection{Socio-Demographic}

The variables consisted socio-demographic background of the respondents for example, youth gender and ethnicity.

\subsubsection{Perception Towards Program Participation}

Five questions were asked from respondents to gain their perception about financial education program participation with multiple answer choices.

\subsubsection{Personal Money Management Topic}

Respondents need to indicate which topic they want to learn in a personal money management program. Participants may choose more than 1 answer.

\subsubsection{Preference to Learn about Money, Money Management and Entrepreneurship}

Respondents were asked their preference to learn about money, money management and entrepreneurship through financial educational program.

\subsection{Data Analysis}

All the gathered data had been entered in to be analyzed by utilizing Statistical Package of the Social Science (SPSS). Descriptive analysis and inferential analysis such as cross-tabulation test was applied to measure the program participation, respondents interested topics and preference to learn about money, money management and entrepreneurship by gender and ethnicity.

\section{Results and Discussion}

\subsection{Respondent Characteristics}

A sum of 220 respondents were participated in this study. More than half (51\%) of the respondents were female. The greater part of the respondents was Malay (42\%), trailed by Indian (34\%) and Chinese (24\%).

\subsection{Program Participation by Respondents' Gender}

Referring to Table 1, results indicated that $76.7 \%$ of females agreed the need for more information to make better financial decision (e.g., saving, borrowing and insurance) while only $63.5 \%$ of males agreed with this statement. Females $(33.3 \%)$ tend to be more interested as compared to males $(21.5 \%)$ if there are given 
opportunities to join program that related to money, personal money management and entrepreneurship. About $50 \%$ of respondents (both male and female) suggested that they are willing to spend one hour per week to attend a session of the program. About $60 \%$ of both males and females preferred the ideal duration to complete the entire program in the duration between one month and three months. About $90.9 \%$ of female respondents perceived that money, money management and entrepreneurship related program can be made as part of their extra co-curricular activities at school while only $68.5 \%$ of male agreed with this suggestion.

Table 1. Crosstab program participation by respondents' gender

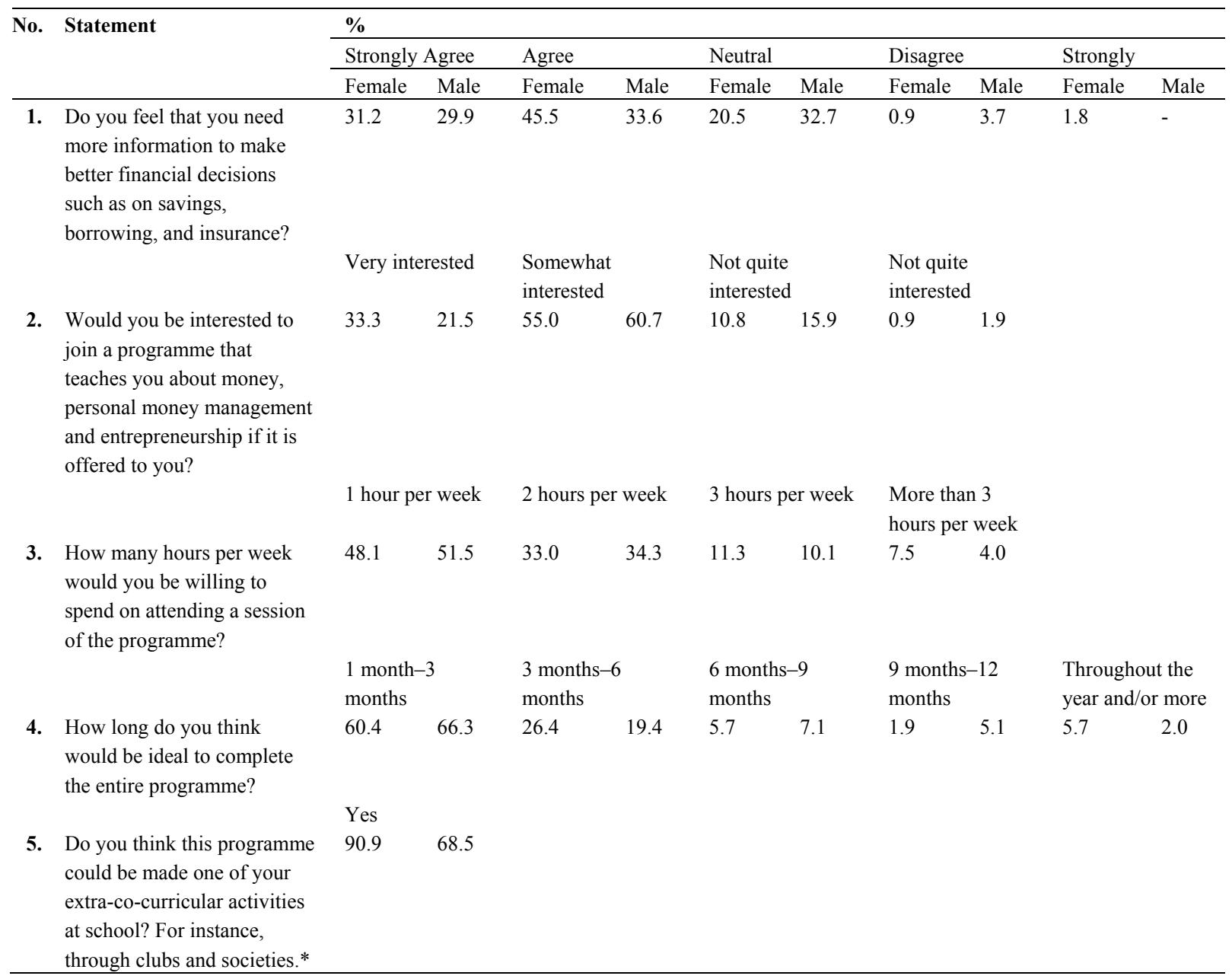

\subsection{Respondents Interested Topic by Gender}

About $80 \%$ of respondents (Male $=79.4 \%$; Female $=84.8 \%$ ) are more interested to the personal money management program that related to the topic of Career and Income (refer to Figure 1). Besides, more male respondents tend to be more interested on the topic of Savings (85.2\%), Investment (57.4\%) and Insurance \& Protection Plan (66.7\%). Female respondents are interested to topics such as Career \& Income (84.8\%), Credit \& Debt (47.3\%), Expenditure (65.2\%) and Entrepreneurship/Business (54.5\%). 


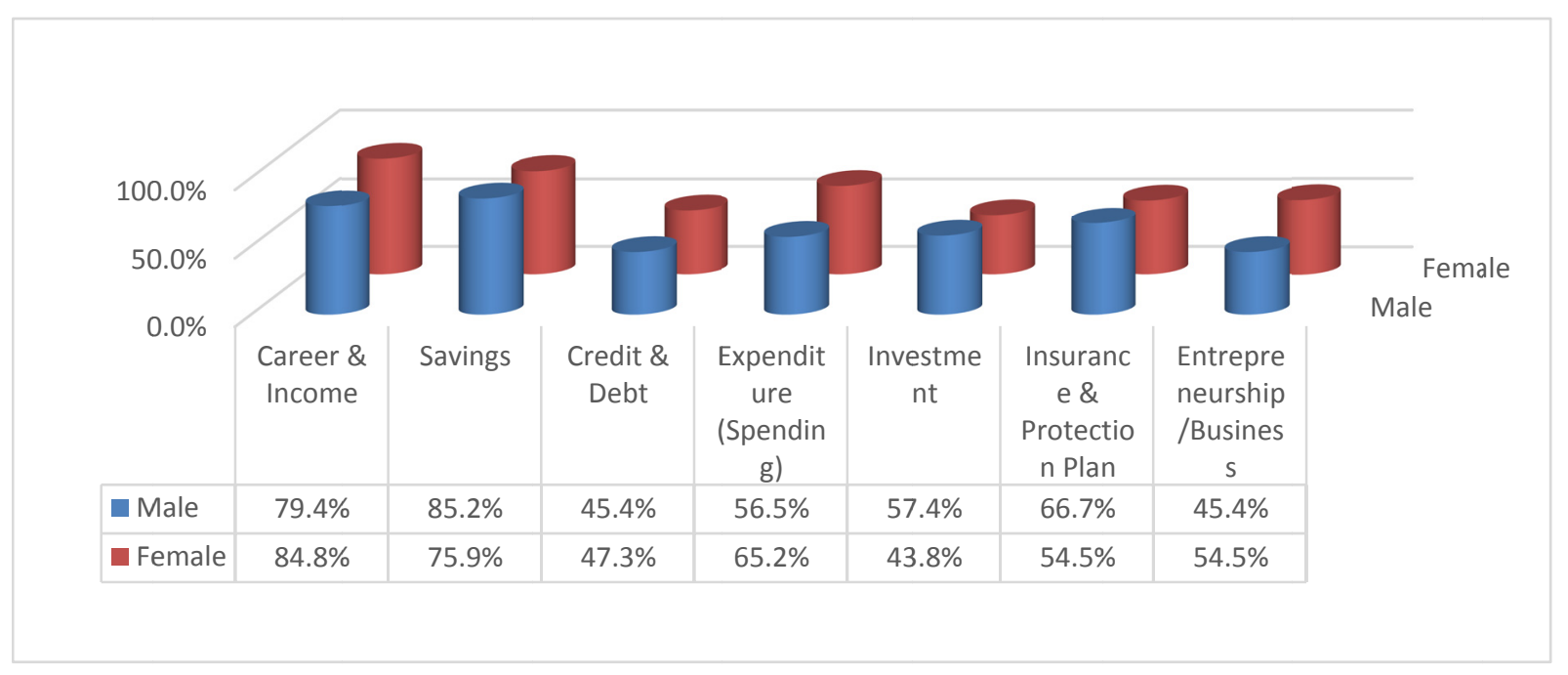

Figure 1. Topic that respondents interested by gender

\subsection{Preference to Learn about Money, Money Management and Entrepreneurship by Gender}

Figure 2 displayed the score between male and female on various learning medium on money, money management and entrepreneurship related knowledge. Results indicated that male respondents tend to learn the knowledge mostly from their parents $(82.4 \%)$, followed by internet $(66.7 \%)$, friends $(52.8 \%)$, field trips $(50 \%)$, television $(49.1 \%)$, talk by industry experts $(45.4 \%)$, reading books $(39.8 \%)$, classroom lectures $(33.3 \%)$ and others. Female respondents more likely to choose field trip (75.9\%) as their primary preference for learning, followed by internet $(60.7 \%)$, classroom lectures $(48.2 \%)$, talk by industry experts $(46.4 \%)$, reading book $(42.9 \%)$, friends $(42 \%)$, television $(38.4 \%)$ and others. Furthermore, significant association also found between male and female on parents, classroom lectures and field trips.

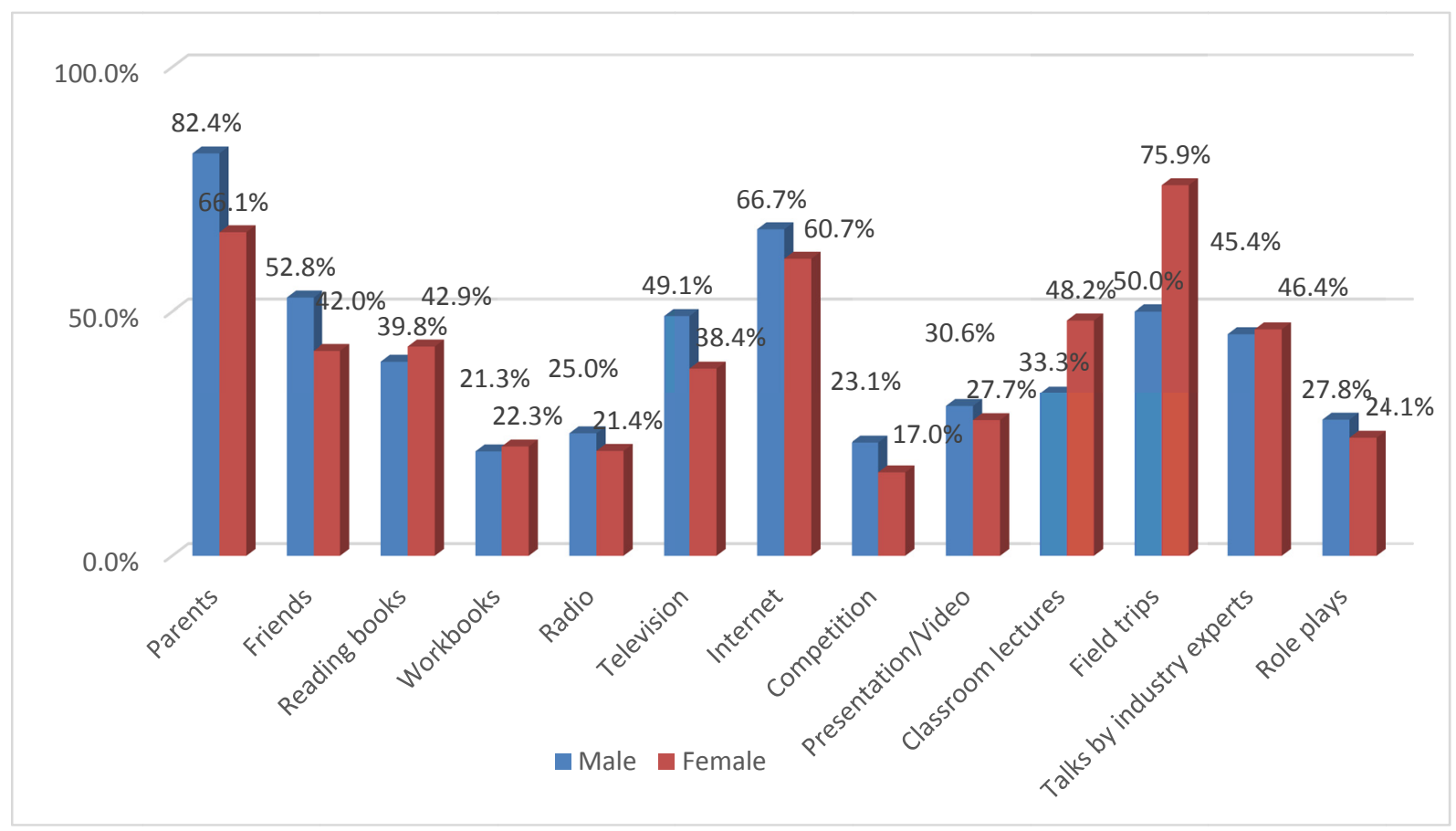

Figure 2. Preference to learn about money, money management and entrepreneurship by gender 


\subsection{Program Participation by Respondents' Ethnicity}

Results indicated a significant association between ethnicity and the need of information to have better financial decision (refer Table 2). A total of $80.5 \%$ of Malay respondents responded that they need more information to enhance their financial decision such as on saving, borrowing and insurance, followed by $64 \%$ of Indians and $61.5 \%$ of Chinese. Besides, $92.3 \%$ of Malay respondents also interested to participate programs related to money, personal money management and entrepreneurship. Only $83.8 \%$ of Indian and $75.5 \%$ of Chinese respondents are interested to join these programs if are offered. Majority of $62.5 \%$ Chinese, followed by $47.1 \%$ of Indians and $44.8 \%$ of Malays voted that they are willing to spend 1 hour per week to attend a session of the program. Besides, about $60 \%$ and more respondents across the ethnic groups tend to complete the entire program within 1 to 3 months' period. Furthermore, both Malay (89\%) and Indian (86.5\%) respondents agreed to implement this program as part of their extra-co-curricular activities at school, while only $54.7 \%$ of Chinese respondents voted for this suggestion.

Table 2. Crosstab programme by respondents' ethnicity

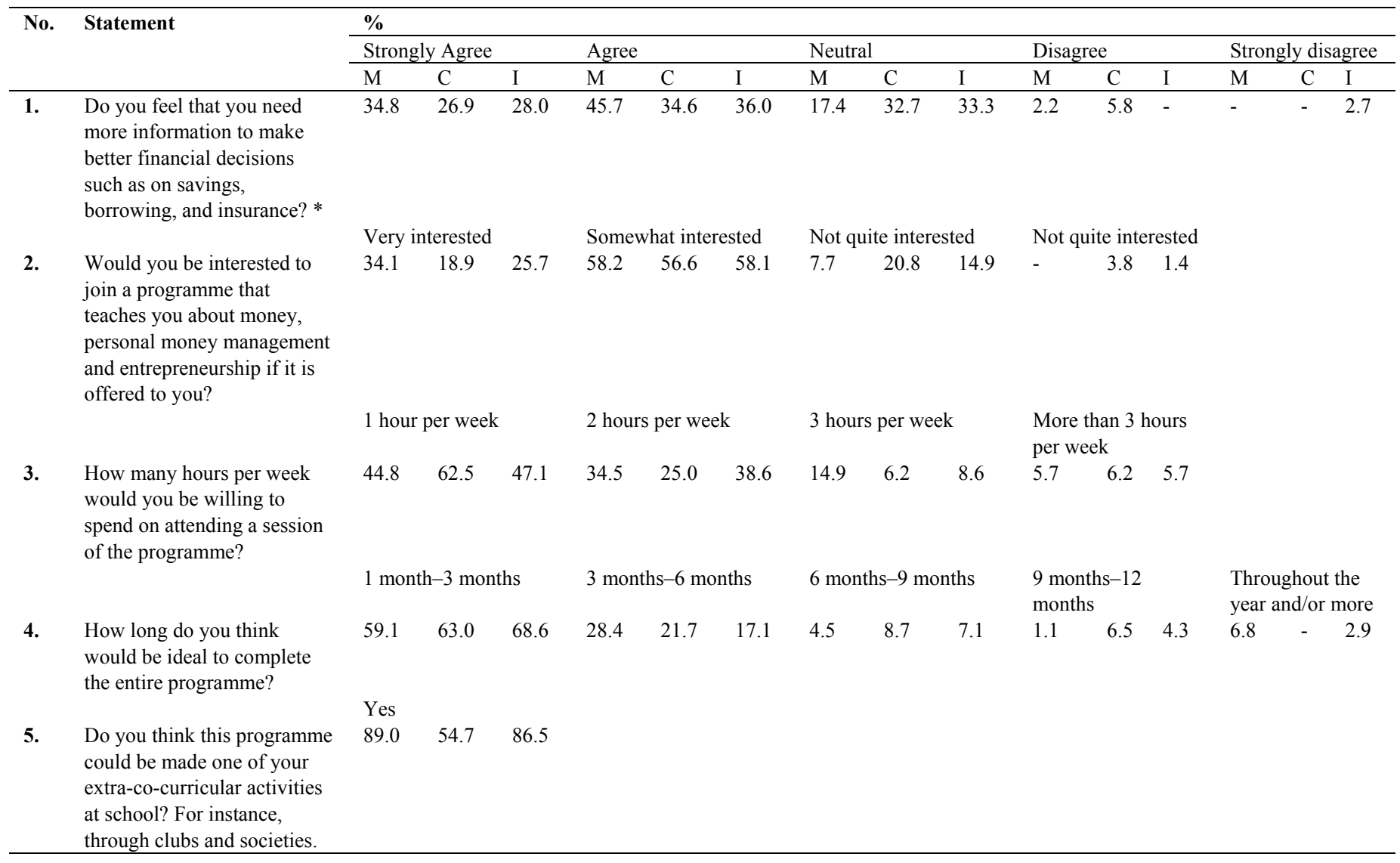

\subsection{Respondents Interested Topic by Ethnicity}

Figure 3 displayed that more Malay respondents interested to the topics of career \& Income (89.1\%), followed by topic related to Saving (87\%), Expenditure (78.3\%), Insurance \& Protection Plan (62\%), Credit \& Debt (58.7\%), Entrepreneurship/Business (57.6) and lastly Investment (54.3\%). Chinese respondents tend to have interest on Saving (79.2\%), Career \& Income (78.8\%) and 58.5\% of Expenditure, Investment and Insurance \& Protection Plan. They are less likely to learn about Credit \& Debt (50.9\%) and Entrepreneurship/Business (47.2\%). Besides, most Indian respondents like to join programs such as Career \& Income (76\%), Savings (73.3\%), Insurance \& Protection Plan (60\%), Entrepreneurship/Business (42.7\%), Expenditure (41.3\%), Investment (41\%) and Credit \& Debt (28\%). 


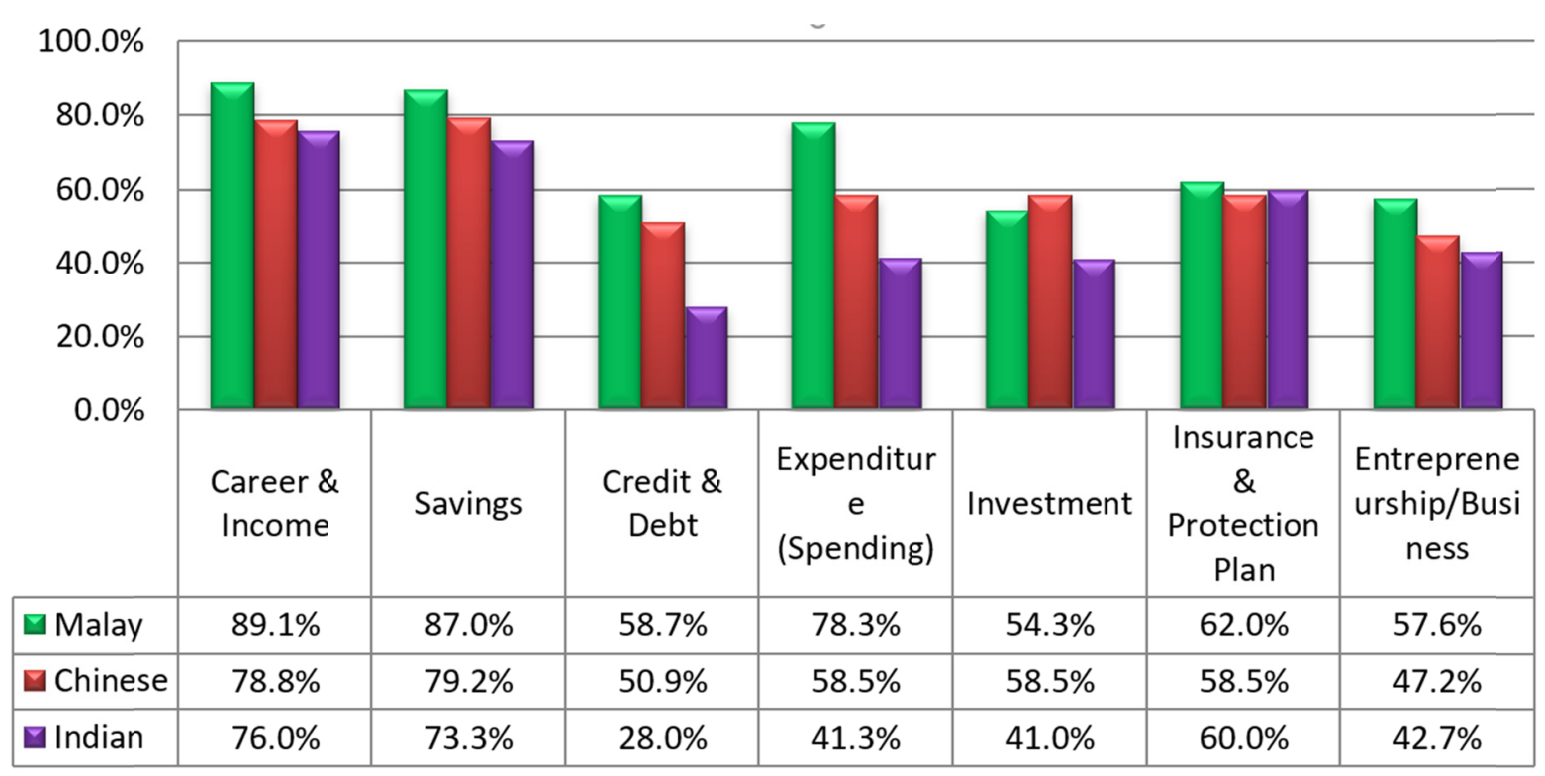

Figure 3. Topic that respondents interested by ethnicity

\subsection{Preference to Learn about Money, Money Management and Entrepreneurship by Gender}

Figure 4 displayed the score between ethnic groups on various learning medium on money, money management and entrepreneurship related knowledge. The results indicated that Malay respondents tend to learn the knowledge mostly from their parents $(78.3 \%)$, followed by field trips $(77.2 \%)$, internet $(67.4 \%)$ and talk by industry experts $(62 \%)$. Chinese respondents reported to prefer talk to their parents $(77.4 \%)$ and search information from internet $(66 \%)$. About $66.7 \%$ of Indians like to talk with their parents regarding this topic, followed by field trips $(65.3 \%)$, search from internet (57.3\%) and from friends (52\%).

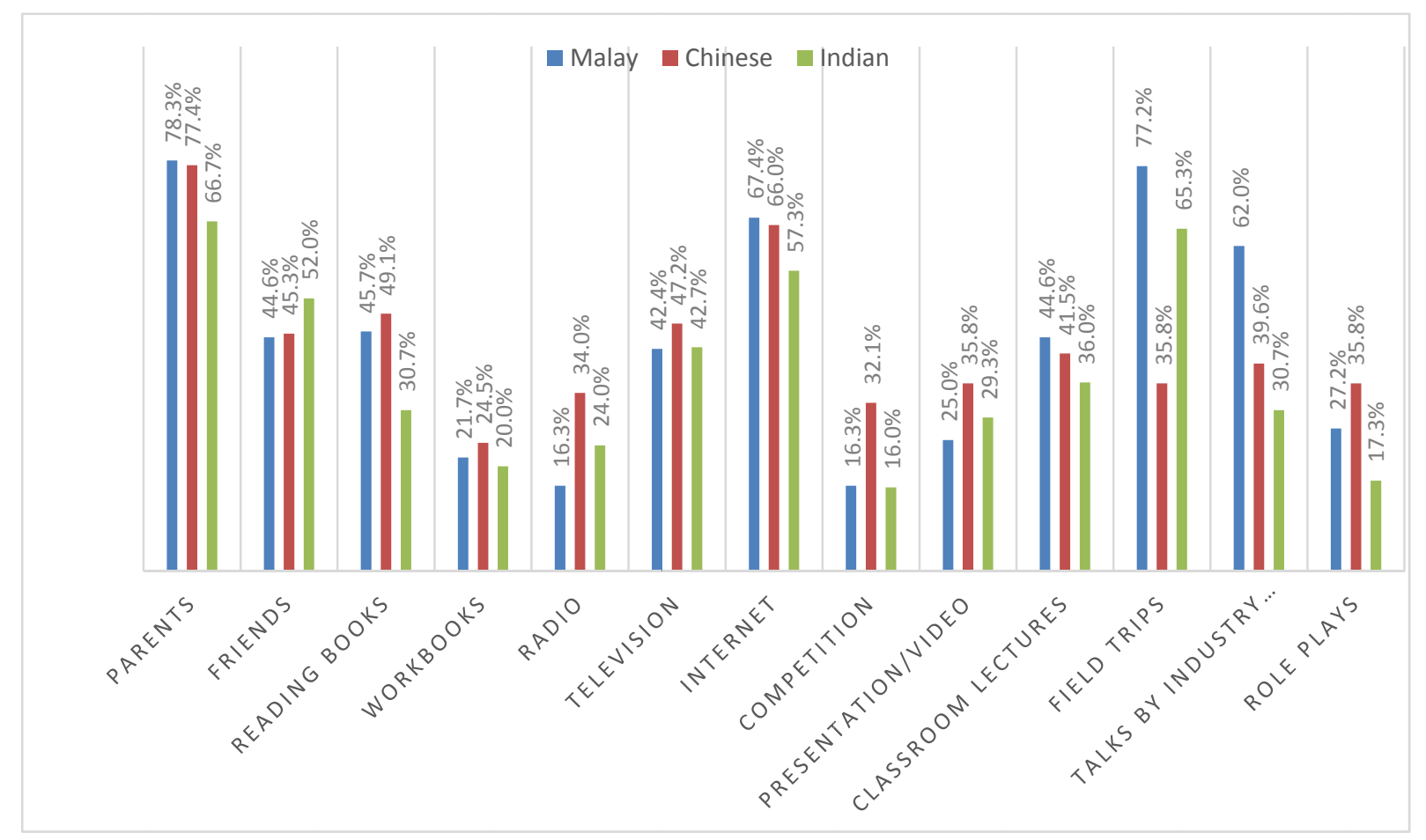

Figure 4. Prefer people to learn about money, money management and entrepreneurship by ethnicity 


\section{Conclusion}

Various designs of financial related programs should take consideration for the need of the target population. The differences of the characteristics and background of the target population may impact on the effectiveness of the program outcome. A holistic perspective with interesting approaches needs to be blended in order to create a fun, enjoyable and informative program. Program development can include some activities that inspire the participants to involve actively in the program. The strategy is aimed to help participants to understand better and to internalize the concept taught in the program eventually. The shift of the education method from more content-based education to experiential learning can be taken as part of the criteria in planning a fruitful module for the program.

As noted, financial management is very critical and important to determine the financial stability, independency and well-being of ones' future. Most of them interested and felt the importance of the need to gather more information in order to make better financial decision. Implementation of such programs as part of the extra co-curricular activities may effectively cover the need and benefits the grassroots level. It is always good to expose this kind of knowledge at younger age and practice them since young age. Besides, effective program may need to consider the different level of people and background (such as their parents). As reported, parents are being voted as the most preferable people for them to learn about money, money management and entrepreneurship across gender and ethnics. Therefore, necessary steps need to be planned by considering the proper financial knowledge of their parents. As parents play an important role in contributing to youth decision, parent-child involvement in the program is highly recommended. It is believed that the successful outcome of the program in creating a healthy and well-manage financial individual will contribute to the economic stability of the country, personal and family well-being as well as create a better future for the younger generation.

Most of the respondents rated to have higher interest in learning about career $\&$ income, saving and expenditure. However, a holistic approach called for multiple level of program that covers overall financial topics can be considered rather than only focus on their interest. Practically, the duration of the program can set between one to three months with one hour per week. It is believed to be able to deliver knowledge to youths effectively.

By noticing the importance of knowledge and attitude in financial practice, there is a need to cultivate them as part of the program so that the youths can be equipped with the skills in making a proper and well-manage financial decision. Necessary follow-up and consultation sessions can be provided according to the need of the population.

\subsection{Limitations of the Study and Recommendations for Future Studies}

In this study, only secondary school students from five schools in Greater Klang Valley/Kuala Lumpur, Malaysia were chosen to gather information. Thus, it has faced the limitation of location-feedbacks. Tested sample size of this investigation was just 220 respondents. Thus, the huge sample size would be discovered extraordinary, is viewed as another constraint of this survey. Furthermore, to collect quantitative data, close ended questionnaire was used and it might force respondents to select a particular response which was not represent their actual output. Some kind of biasness could be occurred in the survey because of the self-administered questionnaire that was used. Therefore, there was a chance to select the correct answer or any other answer that reflect their preference rather than the real practice.

Regardless of a requirement for extra research around there, some agreement exists on steps that ought to be taken to improve in-school monetary instruction at all grade levels. These means include: provide educators with help and preparing instructor information and frames of mind are basic to conveying viable money related training.

To lead investigate on present and future guardians about what and how to instruct their youngsters about funds is basic. We feel these discoveries could enable current guardians to perceive the potential holes in how and what they are showing their youngsters and enlighten potential course remedies. These discoveries could likewise light up current guardians' triumphs and urge them to keep training their kids well. This exploration can likewise advise Millennials and other people who might get ready for family life. We trust these topics give a system to start contemplating the money related training process in their future families. We likewise trust that the sort of future research would be pertinent to money related advisors, organizers, and specialists as they work with people battling in any capacity monetarily.

At long last, we trust that these topics will be utilized as factors in quantitative research that further investigates their quality and effect. In particular, we recommend that future research incorporate longitudinal information, which would follow the utilization of parental budgetary training strategies and standards and connection those 
with youngsters' money related conduct results as developing grown-ups. Significant results to investigate incorporate money related ability and monetary freedom just as potential nonfinancial results, for example, prosocial conduct, marital readiness, etc. Potential mediating or moderating variables that might merit investigating incorporate parent-child connection, gender, class, and numerous different conceivable outcomes for a more extravagant comprehension of parental money related training.

\section{Acknowledgment}

The authors wish to give their sincere gratitude to the "Financial Youth Empowerment Programme" for offering to conduct the study. After that we acknowledge many unknown respondents \& secondary school officials for their valuable opinions \& support for the successfulness of the survey.

\section{References}

Ashby, J. S., Schoon, I., \& Webley, P. (2011). Save Now, Save Later? Linkages Between Saving Behavior in $\begin{array}{llll}\text { Adolescence and Adulthood. European } & \text { Psychologist, } 237 .\end{array}$ https://doi.org/10.1027/1016-9040/a000067

Bachmann, G. R., Roedder-John, D., \& Rao, A. R. (1993). Children's susceptibility to peer group purchase influence: an exploratory investigation. Advances in Consumer Research, 20(1), 463-468. Retrieved from http://acrwebsite.org/volumes/7492/volumes/v20/NA-20.

Beverly, S. G., \& Burkhalter, E. K. (2005). Improving the financial literacy and practices of youths. Children \& Schools, 27(2), 121-124. https://doi.org/10.5539/ijef.v6n6p240

Buijzen, M., \& Valkenburg, P. M. (2003). The impact of television advertising on children's Christmas wishes. Journal of Broadcasting \& Electronic Media, 44(1), 456-471. https://doi.org/10.1207/s15506878jobem4403_7

Caron, A., \& Ward, S. (1975). Gift decisions by kids and parents. Journal of Advertising Research, 15(4), 15-20. https://doi.org/10.1080/00913367.1975.10672603

Churchill, G. A., \& Moschis, G. P. (1979). Television and interpersonal influences on adolescent consumer learning. Journal of Consumer Research, 6(1), 23-35. https://doi.org/10.1086/208745

Clarke, M. C., Heaton, M. B., Israelsen, C. L., \& Eggett, D. L. (2005). The acquisition of family financial roles and responsibilities. Family and Consumer Sciences Research Journal, 33(1), 321-340. https://doi.org/10.1177/1077727X04274117

Collins, M., \& Holden, K. C. (2014). New directions for adult and continuing education (no. 141). Spring 2014@2014 Wiley periodicals, inc. published online in Wiley online library. Retrieved from http://wileyonlinelibrary.com

Cunningham, J. (2000). College student credit card usage and the need for on-campus financial counseling and planning services. Undergraduate Research Journal for the Human Sciences, 12(2), 25-33. Retrieved from http://www.kon.org/urc/cunningham.html.

Edwards, R., Allen, M. A., \& Hayhoe, C. R. (2007). Financial attitudes and family communication about students' finances: the role of sex differences. Communication Reports, 20(2), 90-100. https://doi.org/10.1080/08934210701643719

Greenspan, A. (2002a). Remarks by Chairman Alan Greenspan. Financial literacy. Testimony of Chairman Alan Greenspan before the committee on banking, housing, and urban affairs. U.S. Senate. February 5. Retrieved from http://www.federalreserve.gov/boarddocs/ testimony/2002.

Grinstein-Weiss, M., Spader, J., Yeo, Y., Freeze, E. B., \& Taylor, A. (2011). Teach Your Children Well: Credit Outcomes and Prior Parental Teaching of Money Management. Children and Youth Services Review, 33(1), 78-85. https://doi.org/10.1016/j.childyouth.2010.08.015

Hilgert, M., Hogarth, J., \& Beverly, S. (2003). Household financial management: the connection between knowledge and behavior. Federal Reserve Bulletin, July, 309-322. Retrieved from https://EconPapers.repec.org/RePEc:fip:fedgrb:y:2003:i:jul:p:309-322:n:v.89no.7

Howlett, E., Kees, E., \& Kemp, J. (2008). The Role of Self-Regulation, Future Orientation, and Financial Knowledge in Long-Term Financial Decisions. Journal of Consumer Affairs, 42(2), 223-242. https://doi.org/10.1111/j.1745-6606.2008.00106.x

John, D. R. (1999). Consumer Socialization of Children: A Retrospective Look at Twenty-Five Years of 
Research. Journal of Consumer Research, 26(3), 183-213. https://doi.org/10.1086/209559

Johnson, E., \& Sherraden, M. S. (2007). From financial literacy to financial capability among youth. Journal of Sociology \& Social Welfare, 34(3), 119-145. Retrieved from https://scholarworks.wmich.edu/jssw/vol34/iss3/7.

Kotlikoff, L. J., \& Bernheim, B. D., (2001). Household Financial Planning and Financial Literacy. In J. K. Laurence (Ed.), Essays on Saving, Bequests, Altruism, and Life-Cycle Planning (pp. 427-478). Cambridge, MA: MIT Press. https://doi.org/10.7551/mitpress/2829.001.0001

Kretschmer, T., \& Pike, A. (2010). Links between nonshared friendship experiences and adolescent siblings' differences in aspirations. Journal of Adolescence, 33(1), 101-110. https://doi.org/10.1016/j.adolescence.2009.05.001

Lachance, M. J., \& Legault, F. (2007). College students' consumer competence: identifying the socialization sources. Journal of Research for Consumers, 13(1), 1-5. https://doi.org/10.1111/j.1470-6431.2004.00390.x

Loibl, C., \& Hira, T. K. (2005). Self-directed financial learning and financial satisfaction. Financial Counseling and Planning, 16(1), 11-21.

Lusardi, A., \& Mitchell, O. S. (2007). Financial literacy and retirement preparedness: evidence and implications for financial education. Business Economics, 42(1), 35-44. https://doi.org/10.2145/20070104

Lyons, A. C., Scherpf, E., \& Roberts, H. (2006). Financial education and communication between parents and children. Journal of Consumer Education, 23(1), 64-76.

Martin, A., \& Oliva, J. C. (2001). Teaching children about money: applications of social learning and cognitive learning developmental theories. Journal of Family and Consumer Sciences, 93(2), 26-29.

Masche, J. G. (2010). Explanation of normative declines in parents' knowledge about their adolescent children. Journal of Adolescence, 33(1), 271-284. https://doi.org/10.1016/j.adolescence.2009.08.002

McLeod, J. M., \& O'Keefe, G. J. Jr. (1972). The socialization prospective and communication behavior. In G. Kline \& P. Tichenor (Eds.), Current perspectives in mass communication research (pp. 121-168). Beverly Hills, CA: Sage.

Moore, E. S., \& Bowman, G. D. (2006). Of friends and family: how do peers affect the development of intergenerational influences? Advances in Consumer Research, 33(1), 526-542.

Moschis, G. P. (1985). The Role of Family Communication in Consumer Socialization of Children and Adolescents. Journal of Consumer Research, 11(4), 898-913. https://doi.org/10.1086/209025

Norvilitis, J. M., Merwin, M. M., Osberg, T. M., Roehling, P. V., Young, P., \& Kamas, M. M. (2006). Personality factors, money attitudes, financial knowledge, and credit-card debt in college students. Journal of Applied Social Psychology, 36(6), 1395-1413. https://doi.org/10.1111/j.0021-9029.2006.00065.x

OECD. (2014). PISA 2012 results, Students and money (Vol. vi). OECD publishing.

Otto, A. M. C. (2009). The Economic Psychology of Adolescent Saving. Doctoral thesis. Exeter, England: University of Exeter.

Remund, D. L. (2010). Financial Literacy Explicated: The Case for a Clearer Definition in an Increasingly Complex Economy. Journal of Consumer Affairs, 44(2), 276-295. https://doi.org/10.1111/j.1745-6606.2010.01169.x

Rettig, K. D. (1985). Consumer socialization in the family. Journal of Consumer Education, 3(1), 1-7.

Rhine, S. L. W., \& Toussaint-Comeau, M. (2002). Adult Preferences for the Delivery of Personal Finance Information. Financial Counseling and Planning, 13(2), 11-25.

Roberts, J., \& Jones, E. (2001). Money attitudes, credit card use, and compulsive buying among American college students. Journal of Consumer Affairs, 35(1), 213-240. https://doi.org/10.1111/j.1745-6606.2001.tb00111.x

Sabri, M. F., MacDonald, M., Hira, T. K., \& Jariah, M. (2010). Childhood Consumer Experience and the Financial Literacy of College Students in Malaysia. Family and Consumer Sciences Research Journal, 38(4), 455-467. https://doi.org/10.1111/j.1552-3934.2010.00038.x

Schor, J. B. (2004). Born to buy: The commercialized child and the new consumer culture. New York, NY: Scribner. 
Sherraden, M. S., Johnson, L., Guo, B., \& Elliott, W. (2011). Financial Capability in Children: Effects of Participation in a School-based Financial Education and Savings Program. Journal of Family \& Economic Issues, 32(3), 385-399. https://doi.org/10.1007/s10834-010-9220-5

Sohn, S. H., Joo, S. H., Grable, J. E., Lee, S., \& Kim, M. (2012). Adolescents' financial literacy: The role of financial socialization agents, financial experiences, and money attitudes in shaping financial literacy among South Korean youth. Journal of Adolescence, 35(1), 969-980. https://doi.org/10.1016/j.adolescence.2012.02.002

Toussaint-Comeau, M., \& Rhine, S. L. W. (2000). Delivery of Financial Literacy Programs. Consumer and Community Affairs Division, Federal Reserve Bank of Chicago, USA.

Varcoe, K. P., Martin, A., Devitto, Z., \& Go, C. (2005). Using a financial education curriculum for teens. Financial Counseling and Planning, 16(1), 63-71.

Ward, S. (1974). Consumer socialization. Journal of Consumer Research, 1(1), 1-16. https://doi.org/10.1086/208584

Webley, P. (2005). Children's Understanding of Economics. In M. Barrett \& E. Buchanan-Barrow (Eds.), Children's Understanding of Society (pp. 43-65). New York: Psychology Press.

\section{Copyrights}

Copyright for this article is retained by the author, with first publication rights granted to the journal.

This is an open-access article distributed under the terms and conditions of the Creative Commons Attribution license (http://creativecommons.org/licenses/by/4.0/). 